\title{
Community structure, trophic position and reproductive mode of soil and bark-living oribatid mites in an alpine grassland ecosystem
}

\author{
Barbara M. Fischer $\cdot$ Heinrich Schatz $\cdot$ Mark Maraun
}

Received: 20 January 2010/Accepted: 27 April 2010/Published online: 21 May 2010

(C) The Author(s) 2010. This article is published with open access at Springerlink.com

\begin{abstract}
The community structure, stable isotope ratios $\left({ }^{15} \mathrm{~N} /{ }^{14} \mathrm{~N},{ }^{13} \mathrm{C} /{ }^{12} \mathrm{C}\right)$ and reproductive mode of oribatid mites (Acari, Oribatida) were investigated in four habitats (upper tree bark, lower tree bark, dry grassland soil, forest soil) at two sites in the Central Alps (Tyrol, Austria). We hypothesized that community structure and trophic position of oribatid mites of dry grassland soils and bark of trees are similar since these habitats have similar abiotic characteristics (open, dry) compared with forest soil. Further, we hypothesized that derived taxa of oribatid mites reproducing sexually dominate on the bark of trees since species in this habitat consume living resources such as lichens. In contrast to our hypothesis, the community structure of oribatid mites differed among grassland, forest and bark indicating the existence of niche differentiation in the respective oribatid mite species. In agreement with our hypothesis, sexually reproducing taxa of oribatid mites dominated on the bark of trees whereas parthenogenetic species were more frequent in soil. Several species of bark-living oribatid mites had stable isotope signatures that were similar to lichens indicating that they feed on lichens. However, nine species that frequently occurred on tree bark did not feed on lichens according to their stable isotope signatures. No oribatid mite species could be ascribed to moss feeding. We conclude that sexual reproduction served as preadaptation for oribatid mites allowing them to exploit new habitats and new resources on the bark of trees. Abiotic factors likely are of limited importance for bark-living oribatid mites since harsh abiotic conditions are assumed to favor parthenogenesis.
\end{abstract}

Keywords Stable isotopes - Central Alps - Tree bark - Reproductive mode

B. M. Fischer $(\bowtie) \cdot$ H. Schatz

Institut für Ökologie, Universität Innsbruck, Technikerstrasse 25, 6020 Innsbruck, Austria e-mail: Barbara.Fischer@uibk.ac.at

M. Maraun

Institut für Zoologie und Anthropologie, Universität Göttingen, Berliner Strasse 28, 37073 Göttingen, Germany 


\section{Introduction}

Oribatid mites are among the most abundant soil-living microarthropods reaching densities of up to 500,000 individuals per square meter in forest soil (Schatz and Behan-Pelletier 2008). About 10,000 species are described worldwide (Subías 2004; Schatz 2005) of which 608 are represented in Austria (H. Schatz, unpubl. data). Oribatid mites not only live in soil, but also are abundant and diverse on mosses, lichens, dead wood, rocks and the bark of trees (André 1984; Wunderle 1992; Walter and Proctor 1999; Meier et al. 2002; Erdmann et al. 2007; Lindo and Winchester 2008; Schatz and Behan-Pelletier 2008).

Some taxa of oribatid mites exclusively live on trees or lichens (e.g. Carabodes labyrinthicus, Cymberemaeus cymba, Phauloppia lucorum, Zygoribatula exilis; Colloff 1988; Wunderle 1992; Walter and Behan-Pelletier 1999; Erdmann et al. 2007; Lindo and Winchester 2008) whereas others are found on trees as well as in litter and soil (e.g. Pseudotocepheus sp., Epilohmannia sp., Tectocepheus velatus, Oppiella nova; Proctor et al. 2002; Lindo and Winchester 2006). However, the degree of niche specificity of bark-living oribatid mites is little known. Also, the reasons why some taxa only occur on trees while others live on trees and in soil are little understood. The community structure of bark-living oribatid mites is dominated by evolutionary derived species from "higher" taxonomic groups which mainly reproduce sexually (Erdmann et al. 2006; Maraun et al. 2009). However, the reason for the predominance of sexual reproducing species on the bark of trees is unknown.

About $10 \%$ of all known oribatid mite species reproduce by female parthenogenesis (thelytoky; Norton et al. 1993), a rate much higher than in other invertebrate and vertebrate taxa (Cianciolo and Norton 2006; Avise 2008). The reasons for this high level of asexual reproduction are little understood. One may be the permanent availability of homogeneously distributed dead organic matter in soil systems (Scheu and Drossel 2007). In fact, it has been shown in laboratory experiments that parthenogenetic taxa suffer more than sexual taxa from resource limitations (Domes et al. 2007a). Alternatively, it has been hypothesized that parthenogenesis is favored in environments with few antagonists, e.g. parasites (Red Queen Hypothesis; Van Valen 1973). However, until now no widely accepted single theory on the evolution and maintenance of sexual reproduction exists (West et al. 1999).

For explaining the high local diversity of soil animals trophic niche differentiation has been intensively discussed. Oribatid mite species as well as those of other taxa of soil animals differ significantly in $\delta^{15} \mathrm{~N}$ signatures indicating that they feed on specific resources. Remarkably, the trophic niche of the species appears to be independent of the current location (soil depth) the animals live in the litter and soil matrix (Scheu and Falca 2000). Some of the bark-living species have a very different stable isotope signature compared to soil-living taxa which may result from lichen feeding (Erdmann et al. 2007; Heethoff et al. 2009). In contrast to the local scale, regionally the diversity of soil animal taxa falls below that of aboveground taxa such as beetles, dipterans and hymenopterans. This has been explained by the generalized feeding mode of soil species, their limited level of trophic specialization and by the lack of co-evolutionary interactions between soil species and their resource which often is dead organic material (Scheu and Setälä 2002, Wardle 2002).

The aim of this study was to investigate the species composition, reproductive mode and feeding biology of oribatid mites in forest soils, dry grassland soil and on the bark of trees. First, we hypothesized that compared to forest soils oribatid mite communities and their feeding habits in dry grassland and the bark of trees are more similar, since both 
habitats are dryer and more open than forest soils. Generally, phylogenetically old taxa of oribatid mites occur in wet soils whereas more recent taxa dominate in younger habitats such as the bark of trees and in dry grasslands (Maraun et al. 2009). Second, we hypothesized that the lower bark region near the tree trunk represents a transition zone between the forest soil and the bark habitat, and therefore oribatid mite communities comprise both species from bark and forest soil. To analyze the trophic position of oribatid mite species we analyzed natural variations of stable isotope ratios $\left({ }^{15} \mathrm{~N} /{ }^{14} \mathrm{~N}\right.$, ${ }^{13} \mathrm{C} /{ }^{12} \mathrm{C}$ ) in potential food resources and oribatid mite species. It has been shown previously that stable isotope signatures of litter and soil differ strongly from those of lichens and mosses (Chahartaghi et al. 2005; Erdmann et al. 2007) allowing to ascribe oribatid mite species to different feeding guilds.

Finally, we hypothesized that feeding on living resources (e.g. lichens or living animal prey) favors sexual reproduction since living resources defend themselves. In contrast, feeding on dead resources favors parthenogenetic reproduction since no co-evolutionary interactions occur (Hamilton 2001) and this may be one of the reasons for the high frequency of parthenogenetically reproducing oribatid mite species in soil (Domes et al. 2007a). We therefore hypothesized that sexually reproducing oribatid mite species are more frequent on bark since these species predominantly feed on living resources, i.e. lichens and algae. Since sexual reproduction dominates in more recently evolved taxa of oribatid mites we assume that these taxa dominate on bark.

The different feeding biology and the different reproductive modes in lower and higher oribatid mites may also reflect the two major transitions during oribatid mite evolution; the shift from feeding on dead organic material and reproducing by parthenogenesis to the feeding on living resources and reproducing sexually. The evolution of feeding on lichens or algae from saprophagy as well as the re-evolution of sex from a parthenogenetic ancestor are events that likely occurred in certain oribatid mite lineages (Domes et al. 2007b; Maraun et al. 2009).

\section{Materials and methods}

\section{Study site}

The study was carried out in the alpine region of Tyrol (Austria) since in this region dry grasslands with partly open soil surface and forest patches co-occur locally ensuring that abiotic factors are similar in both habitats. The average size of those forest patches in the grassland sites was about $3,000 \mathrm{~m}^{2}$. Two study sites were investigated (Fliess and Kaunerberg) both located on cambisols lowering variations due to different soil types. In Fliess the largest dry grasslands of Tyrol are located (Fliesser Sonnenhänge at $47^{\circ} 37^{\prime} \mathrm{N}$ and $10^{\circ} 7^{\prime} \mathrm{E}, 830-1,100 \mathrm{~m}$ a.s.l.). Parent rock is gneiss and phyllite, and the predominant soil types are cambisols. Soil pH varies between 6.7 and 7.1. Due to south-facing slopes Fliess is one of the driest areas in the Austrian Alps with an annual precipitation of less than $700 \mathrm{~mm}$ and foehn exposure. The dominating dry grasslands (Mesobrometum erecti, Festucetum valesiacae) are interspersed with shrubs (e.g. Prunus spinosa) and patches of trees, particularly ash (Fraxinus excelsior) and alder (Alnus spp.). Kaunerberg is located in the western part of Tyrol $\left(47^{\circ} 05^{\prime} \mathrm{N}\right.$ and $10^{\circ} 41^{\prime} \mathrm{E}, 1,149 \mathrm{~m}$ a.s.l.). The soil type of the investigated site is cambisol with a low profile depth and a $\mathrm{pH}$ ranging between 5.7 and 6.6. The dry grassland (Festuco-Brometea) is interspersed with shrubs including blackthorn, juniper and barberry. 
Sampling

In May 2006 samples from four locations were taken: (1) forest soil (i.e. litter and soil below ash trees), (2) soil of dry grassland, (3) lower bark (i.e. bark of ash tree trunks near the ground) and (4) upper bark (i.e. bark of an ash tree trunk in $1.50 \mathrm{~m}$ height). Oribatid mites were sampled in a quantitative way using a split corer for the forest soil and dry grassland soil (Petersen 1978), and a knife to remove the bark for the bark of ash trees. Soil samples (diameter $5 \mathrm{~cm}$ ) were divided horizontally into two depth layers; $0-5$ and 5-10 cm. Bark samples (diameter $5 \mathrm{~cm}$ ) consisted of the full bark layer of the trees. Six replicates were taken in each habitat at each of the two study sites. Animals were extracted by heat (Macfadyen 1961) into picric acid and stored in ethanol (75\%).

For stable isotope analyses oribatid mites and their potential food resources were collected from forest soil and dry grassland soil using a shovel to gain sufficient mite biomass for the analyses. For sampling bark-living oribatid mites the bark of ash trees was removed from the trunk using a knife. Oribatid mites from the bark and soil were extracted in a high gradient extractor and collected in saturated salt solution. After determination to species level they were transferred to tin capsules. Smaller oribatid mite species had to be pooled to reach the amount needed for stable isotope analyses (between 3 and 32 individuals per sample, depending on species weight). After drying at $60^{\circ} \mathrm{C}$ for $12 \mathrm{~h}$ the samples were weighed (Sartorius PB 211 D) and stored in a desiccator until analysis.

The potential food resources of forest soil and dry grassland were separated under a dissecting microscope into grass, moss, litter, roots and fine textured soil. Those from bark included lichens, moss and the outer bark layer (uppermost $1 \mathrm{~mm}$ layer) which were separated under a dissecting microscope using scalpel and tweezers. Lichens were determined to species level. All potential food resources were dried at $60^{\circ} \mathrm{C}$ for $12 \mathrm{~h}$ and grounded in a ball mill. The samples were dried again and appropriate amounts (c. 1.3$12.1 \mathrm{mg}$ dry weight) were weighed into tin capsules. The capsules were stored in a desiccator until analysis.

${ }^{15} \mathrm{~N}$ and ${ }^{13} \mathrm{C}$ analysis

The ${ }^{15} \mathrm{~N} /{ }^{14} \mathrm{~N}$ and ${ }^{13} \mathrm{C} /{ }^{12} \mathrm{C}$ ratios were analyzed by a coupled system of an elemental analyzer (NA 1500, Carlo Erba, Milano; Italy) and a mass spectrometer (MAT 251, Finnigan, Bremen, Germany). The composition of nitrogen and carbon isotopes is reported in $\delta$ notation with $\delta^{15} \mathrm{~N}$, respectively $\delta^{13} \mathrm{C}(\%)=\left(R_{\text {sample }}-R_{\text {standard }}\right) / R_{\text {standard }} \times 1,000$. $R_{\text {sample }}$ and $R_{\text {standard }}$ represent the ${ }^{15} \mathrm{~N} /{ }^{14} \mathrm{~N}$, respectively ${ }^{13} \mathrm{C} /{ }^{12} \mathrm{C}$ ratios of the sample and the standard. For ${ }^{15} \mathrm{~N}$ atmospheric nitrogen served as primary standard and acetanilide $\left(\mathrm{C}_{8} \mathrm{H}_{9} \mathrm{NO}\right.$, Merck, Darmstadt) was used for internal calibration. For ${ }^{13} \mathrm{C}$ Vienna Pee Dee Belemnite (V-PDB) served as the primary standard. More details on the analysis are given in Reineking et al. (1993).

\section{Classification of reproductive modes}

The reproductive mode (sexual or parthenogenetic) of oribatid mites was ascribed according to literature data (Norton and Palmer 1991; Norton et al. 1993; Maraun et al. 2003; Cianciolo and Norton 2006; Domes et al. 2007a). For some species no such information was available (Zygoribatula exilis, Scheloribates laevigatus, S. ascendens, Phauloppia lucorum, Caleremaeus monilipes, Eueremaeus oblongus, E. valkanovi, Zetorchestes flabrarius, Pantelozetes paolii). For these species, sex ratios of population samples were 
determined by examining the genitalia (Grandjean 1956a, b); these were observed by light microscopy after clearing specimens with lactic acid. Species were classified as parthenogens when the percentage of males was less than 5\% (Palmer and Norton 1991).

Statistical analysis

Before statistical analysis animal densities of the depths $0-5 \mathrm{~cm}$ and $5-10 \mathrm{~cm}$ were summed up. Differences between relative densities (\% of total) of seven supraspecific groups (at different taxonomic levels) of oribatid mites were analyzed using single-factor MANOVA with the fixed factor habitat (forest soil, grassland soil, lower bark, upper bark) and the seven oribatid mite groups as dependent variables (Enarthronota; Desmonomata; Ptyctima; pycnonotic Apheredermata; dorsodeficient Apheredermata, Eupheredermata and Poronota; cf. Travé et al. 1996; Table 1). In case of a significant MANOVA, protected ANOVAs for the supraspecific groups of the oribatid mites were carried out. Prior to the analyses relative abundances were arcsin-square root transformed.

For a comparison of the four habitat types a Non-metric Multidimensional Scaling (NMDS) was followed by a Discriminant Function Analysis (DFA), using STATISTICA 7.1 (Statsoft, Tulsa, USA). For this analysis the animal densities of the two sites (Fliess, Kaunerberg) were pooled. Species with low abundance $(<3$ occurrences in independent samples) were eliminated. NMDS served to reduce the number of variables (species) of the dataset (Legendre and Legendre 1998). In our study NMDS reduced the number of meaningful dimensions to three. The coordinates of the samples in the 3-dimensional space were subsequently used in DFA with habitat (forest soil, grassland soil, lower bark, upper bark) as grouping variable. Squared Mahalanobis distances between group centroids and the reliability of the sample classifications were determined. Two significant canonical roots were derived and the DFA was graphically presented in 2-dimensional space.

The community structure of the oribatid mites of the four habitats was compared by using Principal Components Analysis (PCA) in CANOCO 4.5 (Ter Braak and Śmilauer 1998). PCA was used if the 'length of gradient' of the ordination was smaller than three indicating that the data do not stretch over a large (hypothetical) environmental gradient. Only species that occurred in more than three independent samples were used for PCA. The four habitats were included in the PCA as supplementary (passive) variables. Data were log-transformed prior to the analysis.

Reproductive modes of oribatid mites in the four habitats were compared using onefactorial analyses of variance (ANOVA) and Tukey's honestly significant difference test for post-hoc comparison. Data on reproductive modes were arcsin-square-root transformed prior to the analyses. MANOVA and ANOVA were performed using SAS 9.13 (SAS Institute Inc., Cary, USA).

\section{Results}

Stable isotope signatures

Fliess: $\delta^{15} \mathrm{~N}$ signatures of the potential food resources of oribatid mites on the bark of trees were highest in outer bark $(2.3 \pm 2.3 \%)$; the respective $\delta^{13} \mathrm{C}$ signature was $-26.4 \pm 1.3 \%$ o (Fig. 1). $\delta^{15} \mathrm{~N}$ signature of mosses was markedly lower $(-2.6 \%$ ) but lowest in the two lichen species Xanthoria parietina $(-4.9 \pm 3.6 \%)$ and Physcia sp. $\left(-9.5 \pm 0.1 \%\right.$ ). In contrast, $\delta^{13} \mathrm{C}$ signature of mosses was lowest $(-29.3 \%)$ and those of 


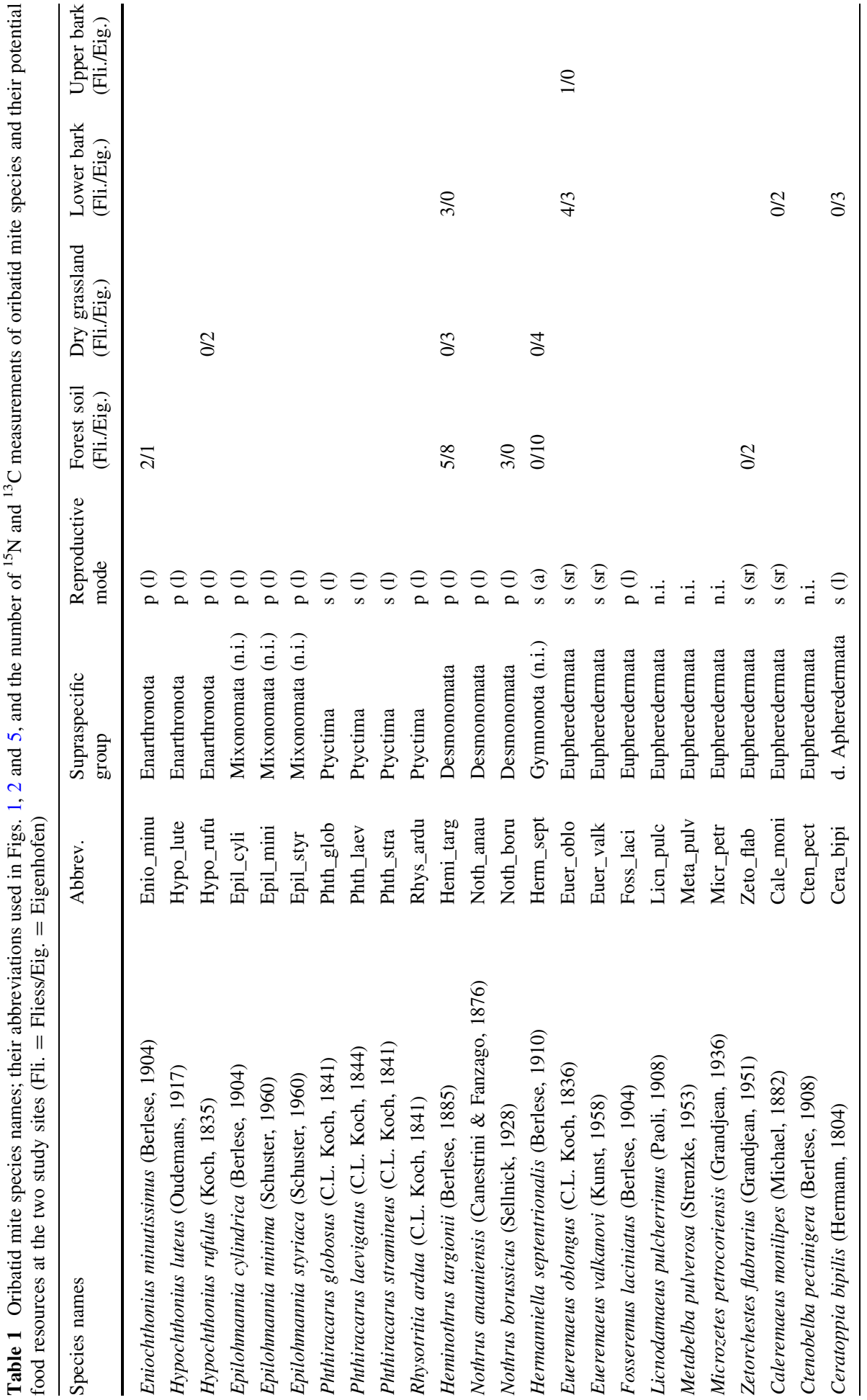




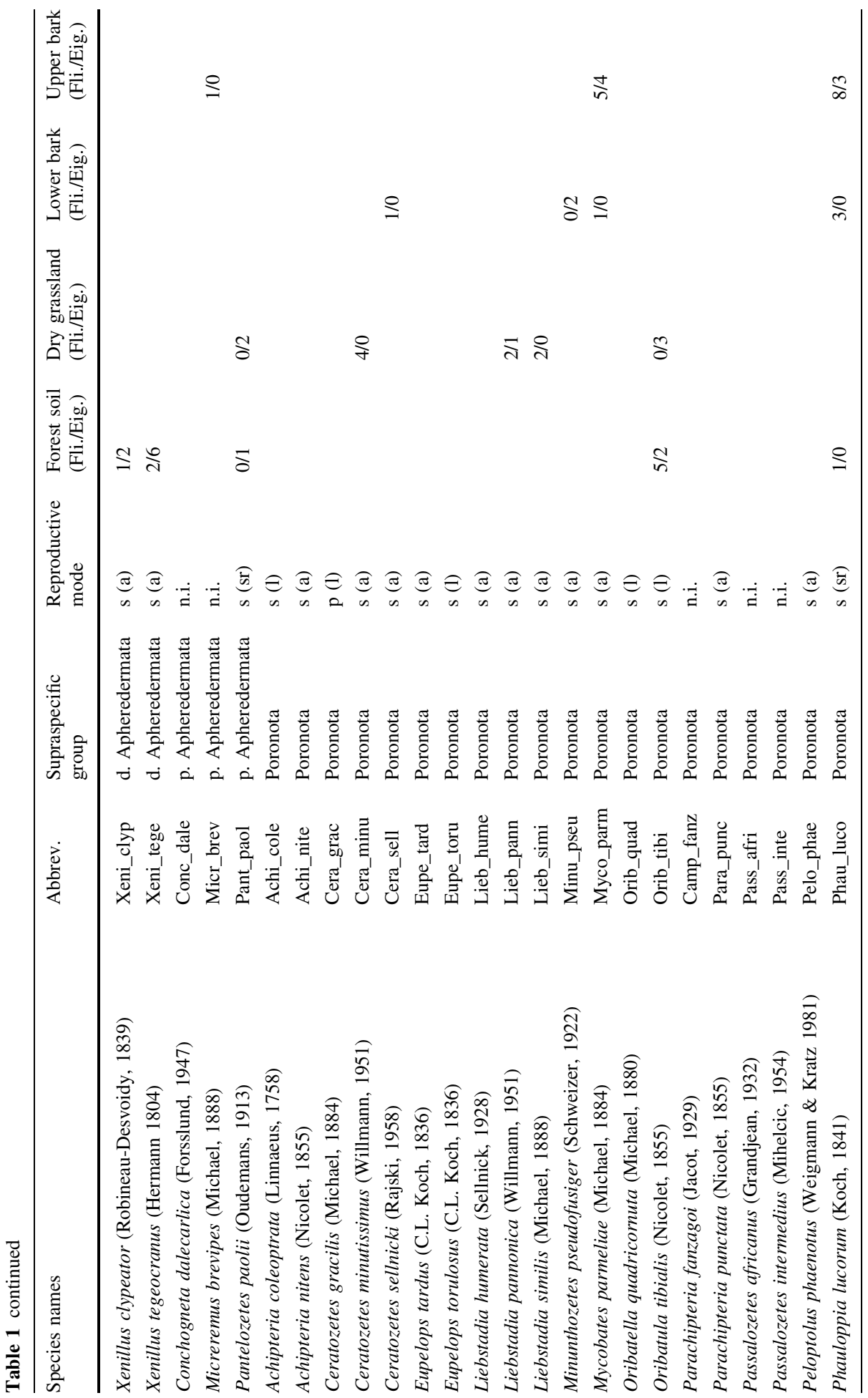




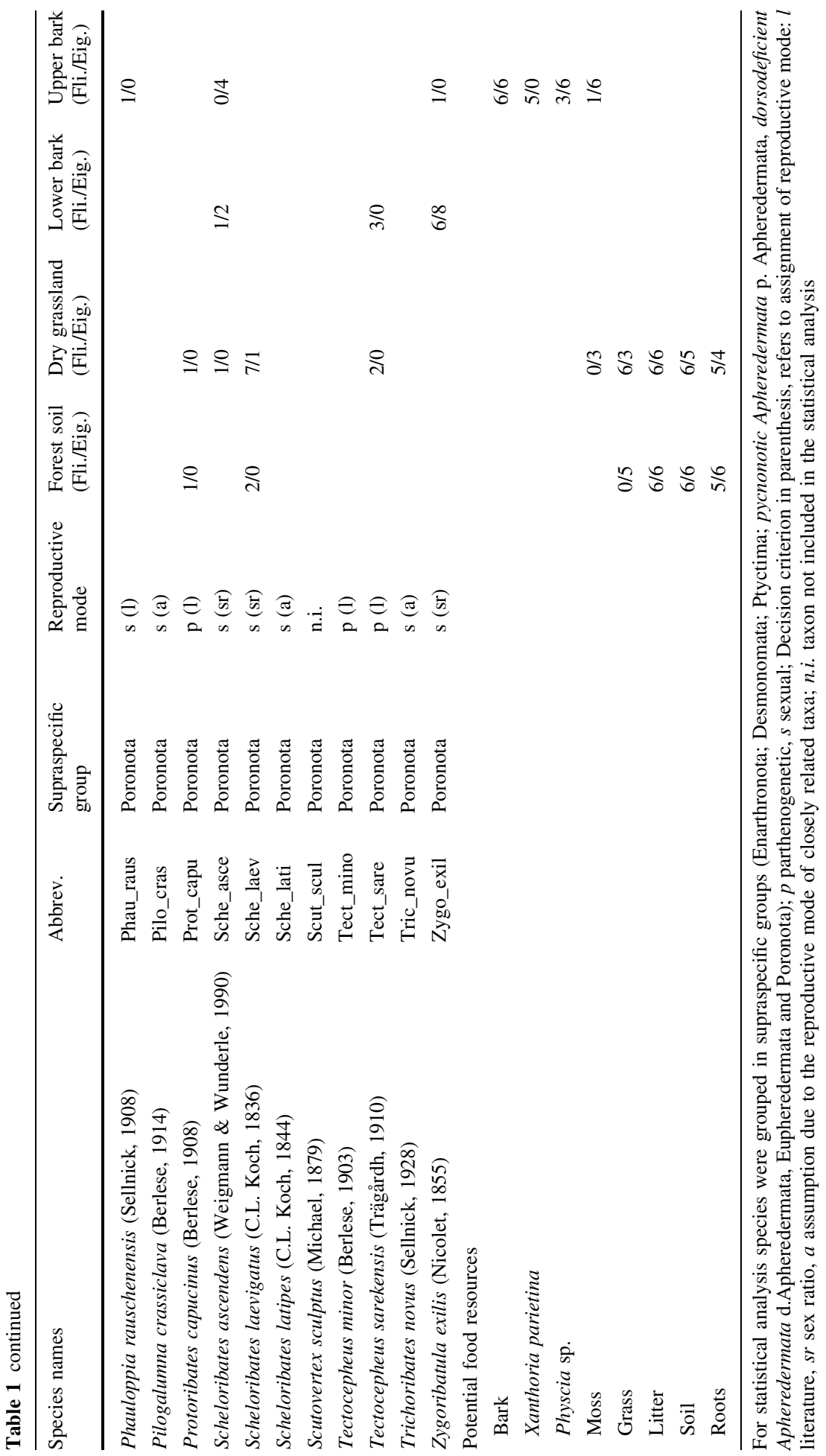




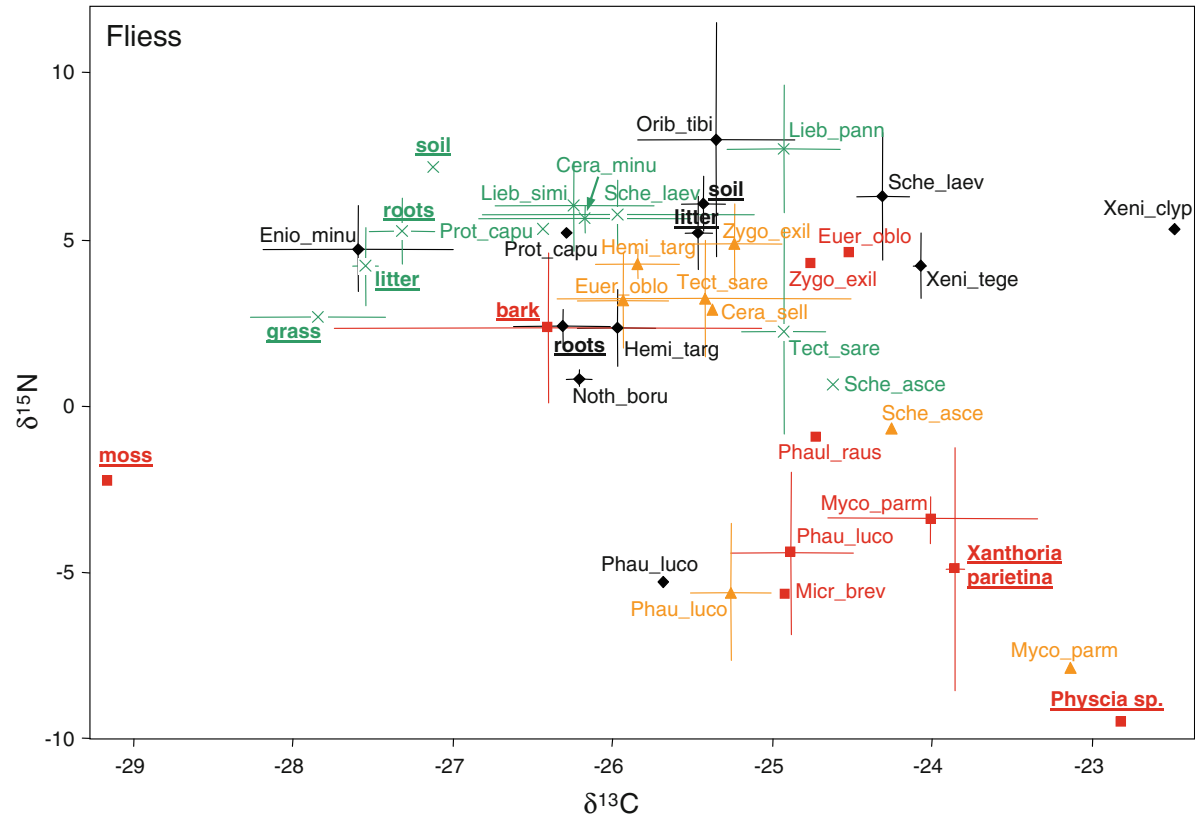

Fig. 1 Mean $( \pm \mathrm{SD})$ of ${ }^{13} \mathrm{C}$ and ${ }^{15} \mathrm{~N}$ values of oribatid mite species and potential resources (underlined) in Fliess (Austria) (filled diamond forest soil, cross grassland soil, filled triangle lower bark, filled square upper bark). Oribatid mite species and resources from the forest soil are shown in black, those from the grassland in green, those from the lower bark in orange and those from the upper bark in red. See Table 1 for full names of species and number of replicates

the two lichen species highest (Xanthoria parietina $-23.8 \pm 0.1 \%$; Physcia sp. $-22.8 \pm 0.1 \%$ ).

Four oribatid mite species from the upper bark (Mycobates parmeliae, Micreremus brevipes, Phauloppia lucorum, Phauloppia rauschenensis) had $\delta^{15} \mathrm{~N}$ and $\delta^{13} \mathrm{C}$ signatures similar those of the two lichen species; however, two oribatid mite species of the upper bark (Eueremaeus oblongus, Zygoribatula exilis) had $\delta^{15} \mathrm{~N}$ and $\delta^{13} \mathrm{C}$ signatures that were closer to those of soil-living oribatid mites (Fig. 1). Three oribatid mite species from the lower bark (Mycobates parmeliae, Phauloppia lucorum, Scheloribates ascendens) also had $\delta^{15} \mathrm{~N}$ and $\delta^{13} \mathrm{C}$ signatures similar to the two lichen species, whereas the other species from the lower bark (Eueremaeus oblongus, Tectocepheus sarekensis, Ceratozetes sellnicki, Heminothrus targonii, Zygoribatula exilis) grouped with the soil-living oribatid mites (Fig. 1). The $\delta^{15} \mathrm{~N}$ and $\delta^{13} \mathrm{C}$ signatures of forest litter and soil were almost identical (litter: $\delta^{15} \mathrm{~N} 5.2 \pm 1.1 \%$, $\delta^{13} \mathrm{C}-25.5 \pm 0.1 \%$; soil: $\delta^{15} \mathrm{~N} 6.1 \pm 0.8 \%$; $\delta^{13} \mathrm{C}-25.4 \pm 0.1 \%$ ) Roots had lower $\delta^{15} \mathrm{~N}(2.4 \pm 0.5 \%)$ and $\delta^{13} \mathrm{C}$ signatures $\left(-26.3 \pm 0.3 \%\right.$ ). The $\delta^{15} \mathrm{~N}$ and $\delta^{13} \mathrm{C}$ signatures of two oribatid mite species from the forest soil (Heminothrus targonii, Nothrus borussicus) were close to those of the roots; Oribatula tibialis had $\delta^{15} \mathrm{~N}$ and $\delta^{13} \mathrm{C}$ signatures that were similar to those of litter and soil in the forest; $\delta^{13} \mathrm{C}$ signatures of two oribatid mite species from the forest soil (Eniochthonius minutissimus, Protoribates capucinus) were much lower than the litter and soil signatures, and three species (Scheloribates laevigatus, Xenillus tegeocranus, Xenillus clypeator) had much higher $\delta^{13} \mathrm{C}$ signatures than the forest litter and soil. The $\delta^{15} \mathrm{~N}$ and $\delta^{13} \mathrm{C}$ signatures of Phauloppia lucorum specimens from the forest soil were similar those from bark. In the grassland 
stable isotope signatures of potential food resources were highest in soil $\left(\delta^{15} \mathrm{~N}\right.$ $7.2 \pm 0.1 \% ; \delta^{13} \mathrm{C}-27.1 \pm 0.1 \%$ ), lower in litter and roots (litter: $\delta^{15} \mathrm{~N} 4.2 \pm 1.2 \%$; $\delta^{13} \mathrm{C}-27.5 \pm 0.1 \%$; roots: $\delta^{15} \mathrm{~N} 5.2 \pm 1.1 \% ; \delta^{13} \mathrm{C}-27.3 \pm 0.2 \%$ ), and lowest in grass $\left(\delta^{15} \mathrm{~N} 2.7 \pm 0.2 \%\right.$; $\delta^{13} \mathrm{C}-27.8 \pm 0.4 \%$ ). Stable isotope signatures of oribatid mites from the grassland were similar to those of forest soil and ranged between 2.3 and 7.7 for $\delta^{15} \mathrm{~N}$ and between -26.0 and -24.6 for $\delta^{13} \mathrm{C}$. The only species that occurred both in the grassland soil and on the lower bark was Scheloribates ascendens.

Kaunerberg: The three potential food resources from the bark of the trees, Physcia sp. (lichen), a moss and the outer bark layer, had stable isotopes signatures that were similar to those of the Fliess site and varied between -9.3 and -2.3 for $\delta^{15} \mathrm{~N}$ and between -29.7 and -24.7 for $\delta^{13} \mathrm{C}$ (Fig. 2). In the forest the soil was slightly enriched in $\delta^{15} \mathrm{~N}(1.0 \pm 0.4 \%$ ) compared to litter and roots $\left(\delta^{15} \mathrm{~N}\right.$ between $-2.6 \%$ and $-1.2 \%$ ). In the grassland the potential food resources-grass, moss, litter and roots-had lower $\delta^{15} \mathrm{~N}$ values (between -5.5 and -1.4$)$ than the soil $(0.2 \%) . \delta^{13} \mathrm{C}$ signatures in forest soil and grassland ranged between $-26.8 \%$ and $-28.8 \%$. Based on stable isotope signatures oribatid mite species grouped similar to the Fliess site. Scheloribates ascendens occurred on the upper and lower bark but had stable isotope signatures that were closer to those of soil- and litter-living species. Other species on the lower bark that did not occur at the Fliess site (Ceratoppia bipilis, Caleremaeus monilipes, Minunthozetes pseudofusiger) had stable isotope signatures that also were close to those of soil- and litter-living oribatid mite species (Fig. 2).

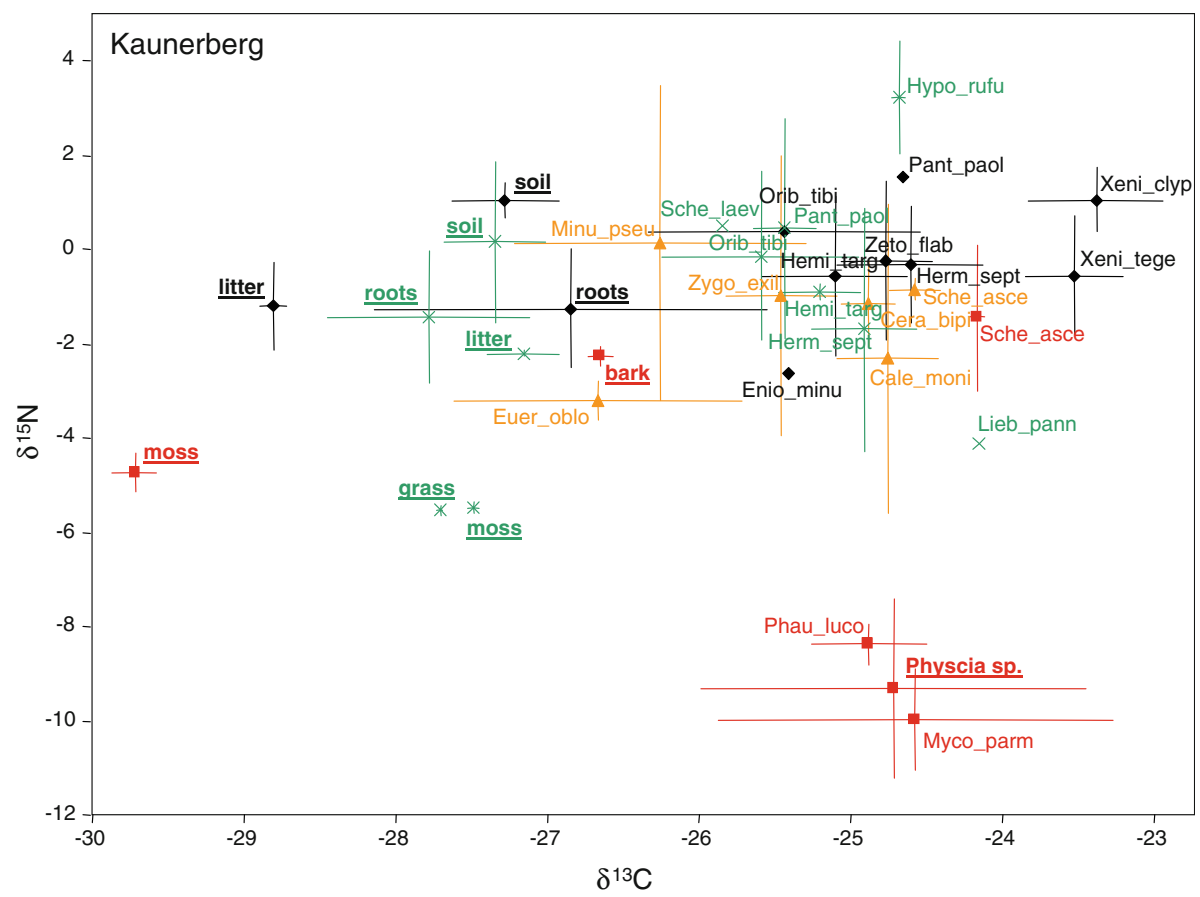

Fig. 2 Mean $( \pm \mathrm{SD})$ of ${ }^{13} \mathrm{C}$ and ${ }^{15} \mathrm{~N}$ values of oribatid mite species and potential resources (underlined) in Kaunerberg (Austria) (filled diamond forest soil, cross grassland soil, filled triangle lower bark, filled square upper bark). Oribatid mite species and resources from the forest soil are shown in black, those from the grassland in green, those from the lower bark in orange and those from the upper bark in red. See Table 1 for full names of species and number of replicates 
Community structure

Supraspecific groups of oribatid mites occurred at different relative densities in the four habitats (MANOVA; Wilks' lambda 0.21, $F_{21,109}=6.1, P<0.0001$ ). Relative densities of five of the seven investigated groups (Enarthronota; Desmonomata; pycnonotic Apheredermata; dorsodeficient Apheredermata and Poronota; Fig. 3) differed significantly among the four habitats. Poronota reached maximum relative density on the bark of the trees, relative density of Eupheredermata was similar in each of the four habitats, and all other oribatid mite groups (Apheredermata, Enarthronota, Desmonomata) reached maximum densities in forest and grassland soil. Ptyctima were generally rare and their density did not differ among habitats (data not shown). Overall, based on the community structure of oribatid mites the habitats differed significantly (DFA; Wilks' lambda 0.03; $F_{9,43}=17.1, \mathrm{P}=0.03$; Fig. 4 ), with each of the individual habitats differing from each other (Squared Mahalanobis distances $>6.4, P<0.05$ ) except grassland and forest soil (Squared Mahalanobis distance 0.98, $\mathrm{P}=0.47$ ).

Principal Components Analysis (PCA) indicated that oribatid mite communities on the lower bark were characterized by Mycobates parmeliae, Scheloribates ascendens, Caleremaeus monilipes, Minunthozetes pseudofusiger and Liebstadia humerata (Fig. 5). In forest soil typical species/taxa included Hypochthonius rufulus, Pantelozetes paolii, Eniochthonius minutissimus, Nothrus anauniensis, Achipteria nitens, Hermanniella septentrionalis, Brachychthoniidae, Quadroppiidae and Oppiidae. Typical species of the grassland soil were Passalozetes africanus, P. intermedius, Pilogalumna crassiclava and

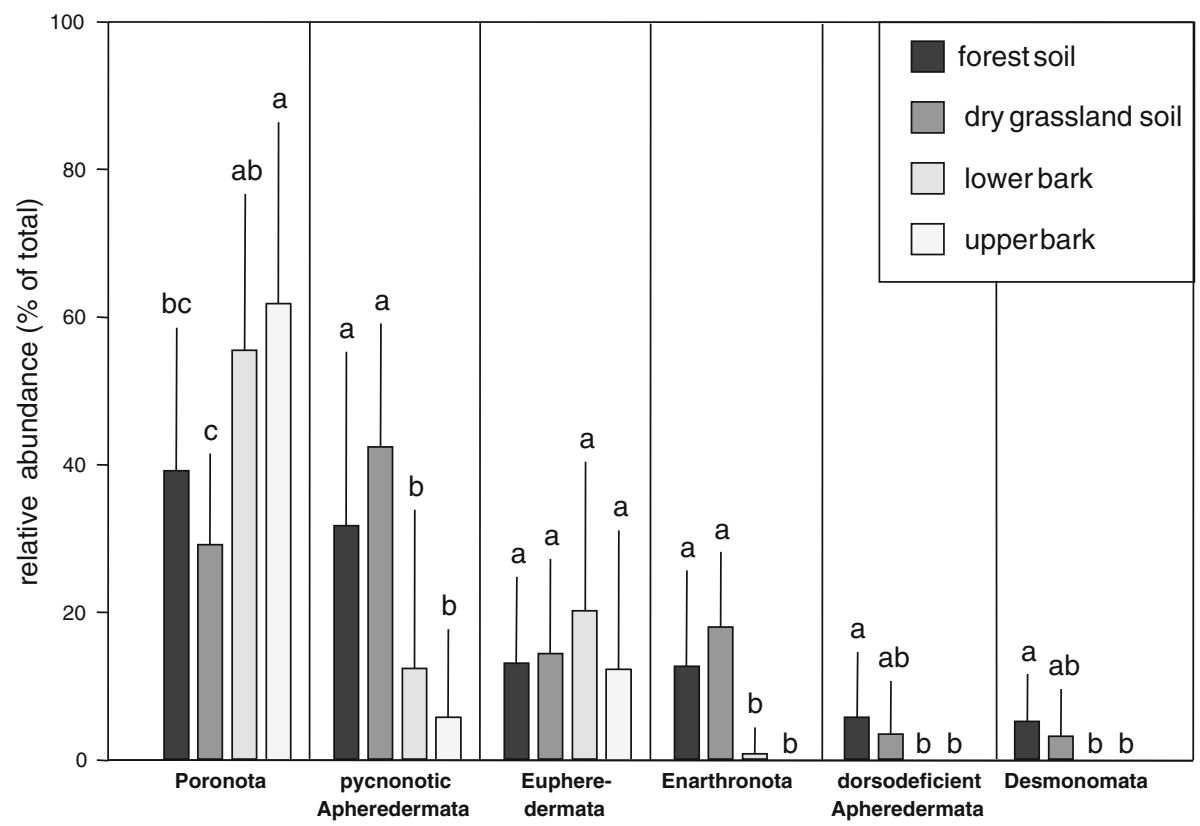

Fig. 3 Relative abundance of six groups of oribatid mites at the four habitats (forest soil, grassland soil, lower bark, upper bark). Ptyctima were not included since their densities were low and did not differ between the four habitats. Data were arc-sin-square-root transformed prior to the analysis. Bars sharing the same letter are not significantly different (Tukey's HSD test; $P>0.05$ ) 


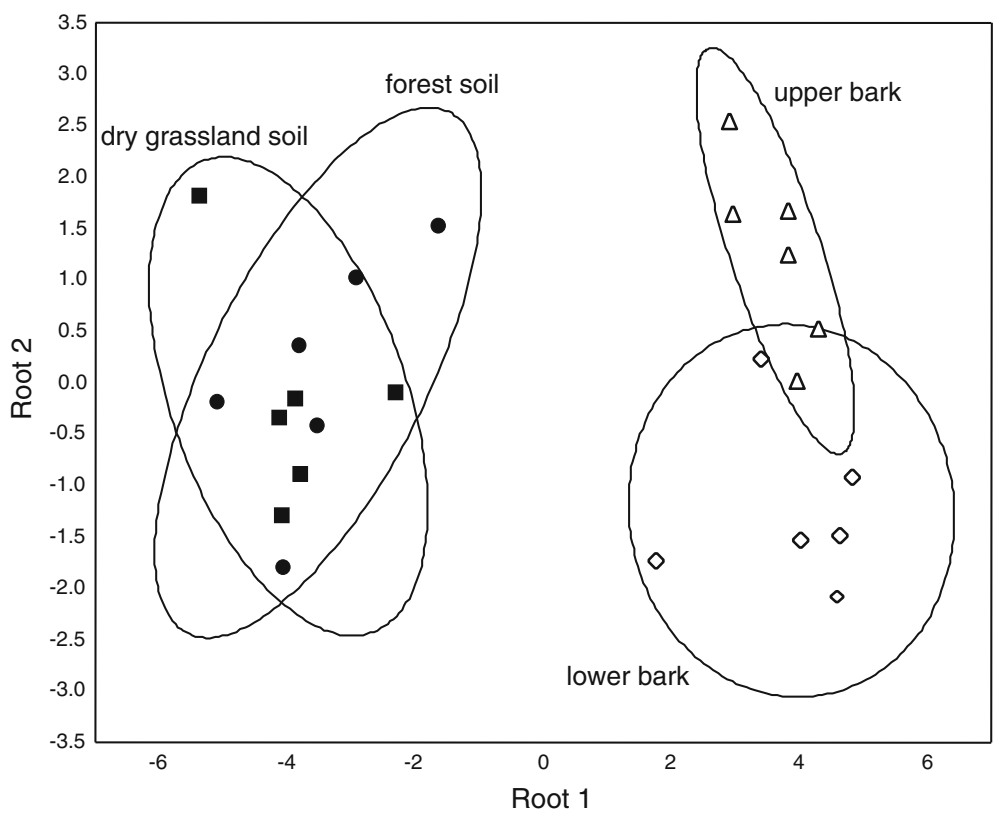

Fig. 4 Discriminant function analysis (DFA) of oribatid mite communities from forest soil, grassland soil, upper bark and lower bark. All habitats differed significantly from each other except grassland and forest soil (for details see text)

Liebstadia pannonica. No oribatid mite species exclusively occurred on the upper bark of trees.

Reproductive mode

The proportion of parthenogenetic individuals of oribatid mites differed significantly among the four habitats (ANOVA: $F_{3,44}=43.4, P<0.0001$; Fig. 6). In the forest and grassland soil, respectively $58 \%$ and $51 \%$ of the individuals were parthenogenetic, respectively. In contrast, on the lower and upper bark only $13 \%$ and $8 \%$ of the individuals were parthenogenetic, respectively and did not differ significantly $(P>0.05)$.

\section{Discussion}

We hypothesized that oribatid mite community structure and feeding habits from grassland soil are similar to those from the bark of trees. The hypothesis was based on the fact that phylogenetically old taxa of oribatid mites, such as Enarthronota, Palaeosomata, Desmonomata and Ptyctima, live mainly in humid soils whereas more recent taxa, especially Brachypylina, dominate in habitats such as the bark of trees and in dry grassland soils (Maraun et al. 2009). Further, we hypothesized that the evolutionary shift from living in forest soil to the colonization of bark, was accompanied by a shift in food resources, i.e. from mainly dead organic matter to living resources, in particular lichens. Our results supported these hypotheses only in part. One of the oribatid mite species that fitted our hypothesis was Scheloribates ascendens. This species occurred on the upper and lower bark but also in dry 
lower bark

forest soil

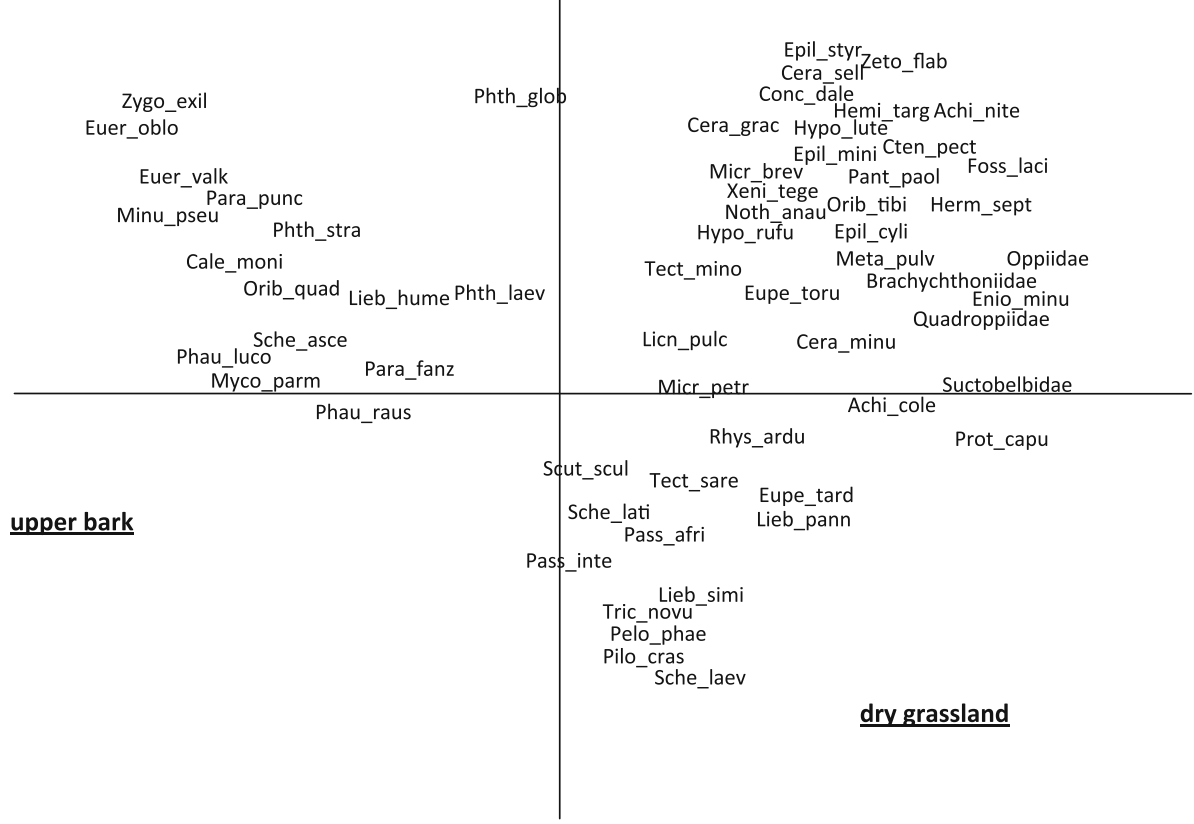

Fig. 5 Principal components analysis (PCA) of oribatid mites of the forest soil, grassland soil, upper bark and lower bark. The four habitats were included as supplementary variables. Data were log-transformed prior to the analysis. See Table 1 for full names of species. Oppiidae, Quadroppiidae, Suctobelbidae and Brachychthoniidae were not determined to species level. Eigenvalues of axes one and two were 0.42 and 0.16 , respectively

Fig. 6 Relative abundance of parthenogenetic individuals of oribatid mites of the forest soil, grassland soil, upper bark and lower bark. Data were arc-sinsquare-root transformed prior to the analysis. Bars sharing the same letter are not significantly different (Tukey's HSD test; $P>0.05)$

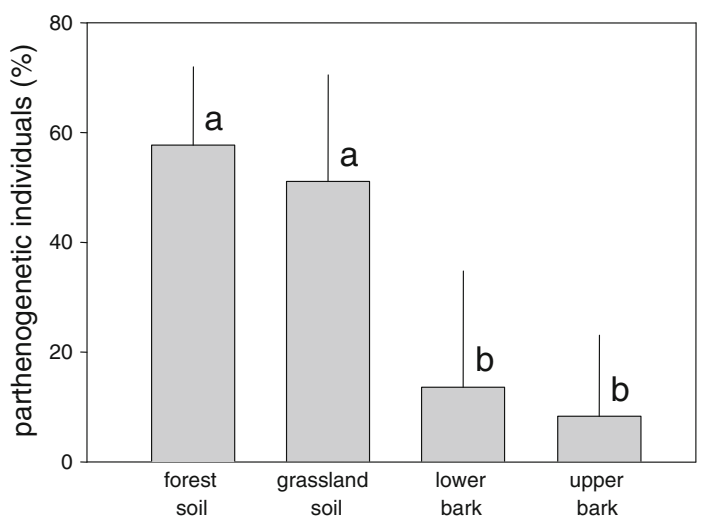

grasslands and its stable isotope signature indicated that at least in part it feeds on lichens. Scheloribates ascendens is a member of the derived Poronota, reproduces sexually and has morphological characteristics related to tree-living including e.g. a clavate sensillus (Karasawa and Hijii 2004; Sobek et al. 2008; Maraun et al. 2009). In contrast to our hypothesis, the community structure of oribatid mites differed between grassland and bark. 
However, the phylogenetic status of bark and grassland taxa in part supports our hypotheses since the bark was inhabited by species belonging to Poronota (e.g. Minunthozetes pseudofusiger, Mycobates parmeliae, Zygoribatula exilis), and species from this group also dominated in grassland soil (e.g. Passalozetes africanus, P. intermedius, Liebstadia pannonica), whereas in forest soil phylogenetically old groups were more frequent (pycnonotic Apheredermata, Enarthronota, Desmonomata). As expected, at least some of the oribatid mite species on bark feed on lichens as indicated by stable isotope signatures (e.g. Micreremus brevipes, Mycobates parmeliae, Phauloppia lucorum, P. rauschenensis, Scheloribates ascendens) which supports other studies (Seyd and Seaward 1984; Behan-Pelletier and Walter 2000; Materna 2000; Erdmann et al. 2006, 2007; Sidorchuk 2009), whereas oribatid mite species of the grassland soil species predominantly live as decomposers or fungal feeders. Overall, the results support the hypothesis that oribatid mites evolved as detritivores in soil and later colonized open habitats such as grasslands and the bark of trees, the latter being associated with the exploitation of living food resources such as lichens.

Notably, not all of the bark-living oribatid mite species had stable isotope signatures similar to lichens indicating that not all of them feed on lichens (Pschorn-Walcher and Gunhold 1957; Bonnet et al. 1975; André 1985; Smrz and Kocourkova 1999). In particular stable isotope signatures of some of the most frequently occurring species on lower bark (Caleremaeus monilipes, Ceratoppia bipilis, Ceratozetes sellnicki, Eueremaeus oblongus, Heminothrus targionii, Minunthozetes pseudofusiger, Tectocepheus sarekensis, Zygoribatula exilis) did not resemble those of lichens. At least some of these species may predominantly feed in soil and colonize the lower bark in search for shelter from predation (Prinzing and Wirtz 1997) or to feed on algae and other resources on bark.

Resource partitioning is one of the main drivers of species diversity and composition in animal communities (Nicolai 1986; Westphal et al. 2006; Bourguignon et al. 2009). It explains in part the high diversity of oribatid mites in forest ecosystems as indicated by stable isotope analysis (Schneider et al. 2004, Erdmann et al. 2007). Lichen feeding in the genus Phauloppia and other oribatid mite taxa can now be taken as granted (Erdmann et al. 2007). However, several bark-living species are unlikely to feed on lichens as indicated by their ${ }^{15} \mathrm{~N}$ signatures, e.g. Zygoribatula exilis, (Eu)eremaeus oblongus. Erdmann et al. (2007) hypothesized that these species feed on algae, mosses or non-lichen fungi. However, mosses sampled from the bark of trees in our study had lower $\delta^{13} \mathrm{C}$ signatures than any of the oribatid mite species indicating that oribatid mites are not (or little) feeding on mosses. Only few oribatid mite species known as habitat and diet generalists occurred in more than one habitat, such as Protoribates capucinus, Achipteria coleoptrata and Suctobelbidae in forest and grassland soil (Schatz 1995; Skubala 1999; Schneider and Maraun 2005).

Oribatid mite species were only occasionally found simultaneously in forest soil and on the lower and upper bark. This supports results of previous studies that trophic niches of oribatid mite species are rather constant independent of their current residence (Scheu and Falca 2000; Schneider et al. 2004). Tectocepheus sarekensis was among the few species occurring on the bark of trees and in grassland and forest soil. This species occurs in a wide range of habitats and suggesting that it is among the most euryoecious and generalistic oribatid mite species (Hågvar and Amundsen 1981; Beckmann 1988; Laumann et al. 2007).

The proportion of parthenogenetic individuals in forest and grassland soils exceeded that of lower and upper bark. This indicates that compared to soil bark species more intensively feed on living resources such as lichens which favours sexual reproduction (Red Queen hypothesis; Hamilton 1980). However, dominance of sexual species may also 
be related to shortage of resources (Scheu and Drossel 2007). Both mechanisms may contribute to the dominance of sexual species on bark. Lichens grow slowly and may be in limited supply but also defend themselves, e.g. by producing usnic acids (Emmerich et al. 1993). Overall, our results suggest that the community of bark-living oribatid mites is not only structured by the harsh abiotic factors but also by biotic interactions. This may explain why in contrast to the general pattern that parthenogenetic reproduction predominates in more harsh environments (Kearney 2005) sexual oribatid mite species predominate on bark.

Acknowledgments We thank Stefan Scheu (Göttingen) and Roy A. Norton (Syracuse) for reading and commenting on earlier versions of the manuscript, and Reinhard Langel (Göttingen) for stable isotope measurement.

Open Access This article is distributed under the terms of the Creative Commons Attribution Noncommercial License which permits any noncommercial use, distribution, and reproduction in any medium, provided the original author(s) and source are credited.

\section{References}

André HM (1984) Notes on the ecology of corticolous epiphyte dwellers. 3. Oribatida. Acarologia 25:385395

André HM (1985) Associations between corticolous microarthoropod communities and epiphytic cover on bark. Holarct Ecol 8:113-119

Avise JC (2008) Clonality. The genetics, ecology and evolution of sexual abstinence in vertebrate animals. Oxford University Press, Oxford

Beckmann M (1988) The development of the soil mesofauna of a ruderal ecosystem as influenced by reclamation measures: 1. Oribatids-Acari: Oribatei. Pedobiologia 31:391-408

Behan-Pelletier VM, Walter DE (2000) Biodiversity of Oribatid mites (Acari: Oribatida) in tree canopies and litter. In: Coleman DC, Hendrix PF (eds) Invertebrates as webmasters in ecosystems. CABI Publishing, Wallingfort, p 187

Bonnet L, Cassagnau P, Travé J (1975) L'Ecologie des Arthropodes muscicoles a la lumiere de l'Analyse des Correspondances: Collemboles et Oribates du Sidobre (Tarn, France). Oecologia 21:359-373. doi: 10.1007/BF00345827

Bourguignon T, Šobotník J, Lepoint G et al (2009) Niche differentiation among neotropical soldierless soilfeeding termites revealed by stable isotope ratios. Soil Biol Biochem 41:2038-2043. doi: 10.1016/j.soilbio.2009.07.005

Chahartaghi M, Langel R, Scheu S, Ruess L (2005) Feeding guilds in collembolan based on nitrogen stable isotope ratios. Soil Biol Biochem 37:1718-1725. doi:10.1016/j.soilbio.2005.02.006

Cianciolo JM, Norton RA (2006) The ecological distribution of reproductive mode in oribatid mites as related to biological complexity. Exp Appl Acarol 40:1-25. doi:10.1007/s10493-006-9016-3

Colloff MJ (1988) Species associations of oribatid mites in lichens on the island of Ailsa-Craig, Firth-ofClyde (Acari, Cryptostigmata). J Nat Hist 22:1111-1119

Domes K, Scheu S, Maraun M (2007a) Resources and sex: soil re-colonization by sexual and parthenogenetic oribatid mites. Pedobiologia 11:1-25. doi:10.1016/j.pedobi.2006.11.001

Domes K, Norton RA, Maraun M et al (2007b) Re-evolution of sex breaks Dollo's law. Proc Natl Acad Sci USA 104:7139-7144. doi:10.1073/pnas.0700034104

Emmerich R, Giez I, Lange OL et al (1993) Toxicity and antifeedant activity of lichen compounds against the polyphagous herbivorous insect Spodoptera littoralis. Phytochem 33:1389-1394

Erdmann G, Floren A, Linsenmair KE et al (2006) Little effect of forest age on oribatid mites on the bark of trees. Pedobiologia 50:433-441. doi:10.1016/j.pedobi.2006.08.004

Erdmann G, Otte V, Langel R et al (2007) The trophic structure of bark-living oribatid mite communities analysed with stable isotopes $\left({ }^{15} \mathrm{~N},{ }^{13} \mathrm{C}\right)$ indicates strong niche differentiation. Exp Appl Acarol 41: 1-10. doi:10.1007/s10493-007-9060-7

Grandjean F (1956a) Caracteres chitineux de l'ovipositor, en structure normale, chez les Oribates (Acariens). Arch Zool Exp Gen Notes et Revue 93:96-106

Grandjean F (1956b) Observations sur les Oribates (33e série). Bull Mus Nat Hist Natur 28:111-118 
Hågvar S, Amundsen P (1981) Effects of liming and artificial acid rain on the mite (Acari) fauna in coniferous forest. Oikos 37:7-20

Hamilton WD (1980) Sex versus non-sex versus parasite. Oikos 35:282-290

Hamilton WD (2001) Narrow roads of gene land. Vol 2, The evolution of sex. Oxford University Press, Oxford

Heethoff M, Norton RA, Scheu S et al. (2009) Parthenogenesis in oribatid mites (Acari, Oribatida). Evolution without sex. In: Schön I, Martens K, Van Dijk P (eds) Lost sex. The evolutionary biology of parthenogenesis. Springer, p 241. doi:10.1007/978-90-481-2770-2_12

Karasawa S, Hijii N (2004) Morphological modifications among oribatid mites (Acari: Oribatida) in relation to habitat differentiation in mangrove forests. Pedobiologia 48:383-394. doi:10.1016/j.pedobi. 2004.05.003

Kearney M (2005) Hybridization, glaciation and geographical parthenogenesis. Trends Ecol Evol 20:495502. doi:10.1016/j.tree.2005.06.005

Laumann M, Norton RA, Weigmann G, Scheu S, Maraun M, Heethoff M (2007) Speciation in the parthenogenetic oribatid mite genus Tectocepheus (Acari, Oribatida) as indicated by molecular phylogeny. Pedobiologia 51:111-122. doi:10.1016/j.pedobi.2007.02.001

Legendre P, Legendre L (1998) Numerical ecology. Elsevier

Lindo Z, Winchester NN (2006) A comparison of microarthropod assemblages with emphasis on oribatid mites in canopy suspended soils and forest floors associated with ancient western redcedar trees. Pedobiologia 50:31-41. doi:10.1016/j.pedobi.2005.09.002

Lindo Z, Winchester NN (2008) Scale dependent diversity patterns in arboreal and terrestrial oribatid mite (Acari: Oribatida) communities. Ecography 31:53-60. doi:10.1111/j.2007.0906-7590.05320.x

Macfadyen A (1961) Improved funnel-type extractors for soil arthropods. J Animal Ecol 30:171-184

Maraun M, Heethoff M, Scheu S et al (2003) Radiation in sexual and parthenogenetic oribatid mites (Oribatida, Acari) as indicated by genetic divergence of closely related species. Exp Appl Acarol 29:265-277. doi:10.1023/A:1025833814356

Maraun M, Erdmann G, Schulz G et al (2009) Multiple convergent evolution of arboreal life in oribatid mites indicates the primacy of ecology. Proc Roy Soc Lond B 276:3219-3227. doi:10.1098/ rspb.2009.0425

Materna J (2000) Oribatid communities (Acari: Oribatida) inhabiting saxicolous mosses and lichens in the Krkonoše Mts. (Czech Republic). Pedobiologia 44:40-62

Meier FA, Scherrer S, Honegger R (2002) Faecal pellets of lichenivorous mites contain viable cells of the lichen-forming ascomycete Xanthoria parietina and its green algal photobiont, Trebouxia arboricola. Biol J Linn Soc 76:259-268

Nicolai V (1986) The bark of trees: thermal properties, microclimate and fauna. Oecologia 21:148-160. doi: 10.1007/BF00399052

Norton RA, Palmer SC (1991) The distribution, mechanisms, and evolutionary significance of parthenogenesis in oribatid mites. In: Murphy PW, Schuster R (eds) The acari: reproduction, development and life-history strategies. Chapman and Hall, London, p 107

Norton RA, Kethley JB, Johnston DE (1993) Phylogenetic perspectives on genetic systems and reproductive modes of mites. In: Wrensch DL, Ebbert MA et al (eds) Evolution and diversity of sex ratio in insects and mites. Chapman and Hall, New York, p 8

Palmer SC, Norton RA (1991) Taxonomic, geographic and seasonal distribution of thelytokous parthenogenesis in the Desmonomata (Acari: Oribatida). Exp Appl Acarol 12:67-81

Petersen H (1978) Some properties of two high gradient extractors for soil microarthropods, and an attempt to evaluate their extraction efficiency. Natura Jutlandica 20:95-121

Prinzing AJ, Wirtz HP (1997) The epiphytic lichen, Evernia prunastri, as a habitat for arthropods: shelter from desiccation, food-limitation and indirect mutualism. In: Stork NE, Adis JA, Didham RK (eds) Canopy arthropods. Chapman \& Hall, London, p 477

Proctor HC, Montgomery KM, Rosen KE et al. (2002) Are tree trunks habitats or highways? A comparison of oribatid mite assemblages from hoop-pine bark and litter. Austr J Entomol 41:294-299. doi: 10.1046/j.1440-6055.2002.00309.x

Pschorn-Walcher H, Gunhold P (1957) Zur Kenntnis der Tiergemeinschaft in Moos- und Flechtenrasen an Park- und Waldbäumen. Z Morph Ökol Tiere 46:342-354

Reineking A, Langel R, Schikowski J (1993) ${ }^{15} \mathrm{~N},{ }^{13} \mathrm{C}$-on-line measurements with an elemental analyser (Carlo Erba, NA 1500), a modified trapping box and a gas isotope mass spectrometer (Finnigan, MAT 251). Environ Health Stud 29:169-174

Schatz H (1995) Hornmilben in Trockenrasenböden des Virgentales (Osttirol, Österreich) 2. Teil: Faunistik (Acari, Oribatida). Ber nat-med Verein Innsbruck 82:121-144 
Schatz H (2005) Diversity and global distribution of oribatid mites-evaluation of the present state of knowledge. Phytophaga 14:485-500

Schatz H, Behan-Pelletier VM (2008) Global diversity of oribatids (Oribatida: Acari: Arachnida). Hydrobiol 595:323-328. doi:10.1007/s10750-007-9027-z

Scheu S, Drossel B (2007) Sexual reproduction prevails in a world of structured resources in short supply. Proc Roy Soc Lond B 274:1225-1231. doi:10.1098/rspb.2007.0040

Scheu S, Falca M (2000) The soil food web of two beech forests (Fagus sylvatica) of contrasting humus type: stable isotope analysis of a macro- and a mesofauna-dominated community. Oecologia 123:285296

Scheu S, Setälä H (2002) Multitrophic interactions in decomposer food webs. In: Tscharntke T, Hawkins BA (eds) Multitrophic level interactions. Cambridge University Press, Cambridge, p 223

Schneider K, Maraun M (2005) Feeding preferences among dark pigmented fungal taxa ("Dematiacea") indicate limited trophic niche differentiation of oribatid mites (Oribatida, Acari). Pedobiologia 49: 61-67. doi:10.1016/j.pedobi.2004.07.010

Schneider K, Migge S, Norton RA et al (2004) Trophic niche differentiation in soil microarthropods (Oribatida, Acari): evidence from stable isotope ratios $\left({ }^{15} \mathrm{~N} /{ }^{14} \mathrm{~N}\right)$. Soil Biol Biochem $36: 1769-1774$. doi:10.1016/j.soilbio.2004.04.033

Seyd EL, Seaward MRD (1984) The association of oribatid mites with lichens. Zool J Linn Soc 80:369-420

Sidorchuk EA (2009) New data on the fauna of oribatid mites (Acari, Oribatida) from the polar Urals. Entomol Rev 89:554-563. doi:10.1134/S0013873809050054

Skubala P (1999) Colonization of a dolomitic dump by oribatid mites (Acari, Oribatida). Pedobiologia 43:145-159

Smrz J, Kocourkova J (1999) Mite communities of two epiphytic lichen species (Hypogymnia physodes and Parmelia sulcata) in the Czech Republic. Pedobiologia 43:385-390

Sobek S, Kampichler C, Weigmann G (2008) Oribatid mites (Acari: Oribatida) in the canopy of a Central European mixed forest: Species richness and species similarity between tree species and habitat types. In: Floren A, Schmidl J (eds) Canopy arthropod research in Europe. Bioform entomology, Nuremberg, p 339

Subías L (2004) Listado sistemático, sinonímico y biogeográfico de los Ácaros Oribátidos (Acariformes, Oribatida) del mundo (1748-2002). Graellsia 60:3-305

Ter Braak CJF, Šmilauer P (1998) CANOCO reference manual and user's guide to CANOCO for windows: software for Canonical Community Ordination (version 4). Microcomputer Power. Ithaca, New York

Travé J, André HM, Taberly G, Bernini F (1996) Les Acariens Oribates. Editions AGAR and SIALF, Belgium

Van Valen LM (1973) A new evolutionary law. Evol Theory 1:1-30

Walter DE, Behan-Pelletier VM (1999) Mites in forest canopies: filling the size distribution shortfall? Ann Rev Entomol 44:1-19. doi:10.1146/annurev.ento.44.1.1

Walter DE, Proctor HC (1999) Mites. Ecology, evolution and behavior. CABI Publishing, Wallingford

Wardle DA (2002) Communities and ecosystems: linking the aboveground and belowground components. Princeton University Press, Princeton

West SA, Lively CM, Read AF (1999) A pluralist approach to sex and recombination. J Evol Biol 12:10031012

Westphal C, Steffan-Dewenter I, Tscharntke T (2006) Bumblebees experience landscapes at different spatial scales: possible implications for coexistence. Oecologia 149:289-300. doi:10.1007/s00442-006-0448-6

Wunderle I (1992) Die Oribatiden-Gemeinschaften (Acari) der verschiedenen Habitate eines Buchenwaldes. Carolinea 50:79-144 